\title{
Capital Market Determinants and Market Capitalization in Nigeria
}

\author{
Cordelia Onyinyechi Omodero ${ }^{1}$ \\ ${ }^{1}$ Clifford University Owerrinta, Abia State, Nigeria \\ Correspondence: Cordelia Onyinyechi Omodero, Clifford University Owerrinta, Abia State, Nigeria.
}

Received: September 30, 2019

Accepted: December 18, 2019 Online Published: December 19, 2019

doi:10.5430/ijfr.v11n1p462

URL: https://doi.org/10.5430/ijfr.v11n1p462

\begin{abstract}
Capital market plays a crucial role in a country's national development and economic capacity building. However, there are economic forces that determine the success of a capital market development in every nation. This study investigates the role of these economic indicators in determining the capital market performance in Nigeria using secondary data covering a period from 1998 to 2018. These data have been sourced from the World Bank Development Indicators, International Monetary Fund and CBN Statistical Bulletin, 2018 edition. The results from the regression analysis indicate that exchange rate and inflation rate have immaterial undesirable consequence on capital market capitalization (CMC) while the interest rate exerts a weighty harmful effect on CMC. The study also provides evidence that the gross domestic product (GDP) has a substantial positive impact on CMC. The study among others suggests that the growth of the economy should be sustained in order to keep boosting the capital market. However, the economic indicators such as inflation, interest rate and exchange rate should be kept under strict control by the relevant authorities in the country.
\end{abstract}

Keywords: capital market, market capitalization, exchange rate, GDP, inflation, interest rate

JEL Classifications: G15, E44, E31, E43, F31

\section{Introduction}

Capital market represents an extensive variety of marketable assets which comprise the stock market as well as other venues for trading different financial products, but the stock market allows investors and banking institutions to trade stocks, either privately or publicly (Investopedia, 2019). Capital markets consist of primary and secondary markets where financial securities including bonds, derivative contracts such as options, various loans, commodity futures and other debt instruments are traded (Investopedia, 2019). Capital market in Nigeria provides a platform whereby government stocks/securities, debt instrument or bonds, equities and exchange trust fund (ETF) introduced in 2011 can be traded. The Nigerian Stock Exchange regulates and oversees the development and activities of the capital market. A stock trade market is a foundation that provides a connection between purchasers and dealers of securities to come into exchange. Talla (2013) presents that stock trade is the focal point of a system of exchanges where purchasers and merchants trade protections and furthermore decide their costs. Securities exchange gives long haul assets to recorded organizations in stock trades by pooling in assets from different speculators which enable organizations to grow their organizations and furthermore give financial specialists elective venture openings (Golam, Wali, Ashraful, Alam and Khan, 2017). Financial exchange is the motor of an economy which assembles capital for corporate associations and offers speculation alternatives to the national, universal, institutional and singular speculators who for the most part target boosting their arrival and riches (Nijam, Ismail and Musthafa, 2015). Securities exchange assumes an essential job in the activation of capital in developing and industrialized nations, prompting the development of industry and trade of the nation, which is the resultant impact of arrangements on progression and globalization grasped by most creating and propelled governments. In every single developing economy, securities exchanges depict the genuine image of the money related strength of the economy to such an extent that weights from macroeconomic factors on financial exchange returns are typically assessed to appropriately control speculators and other market players.

In any case, the nearness and instability of macroeconomic elements give a sign to financial exchange members to envision of a higher or lower return when putting resources into a stock. The varieties in macroeconomic factors can altogether effect on securities exchange costs. The impacts of macroeconomic factors on financial exchange stimulates the enthusiasm of both the business analysts and speculators (Barakat, Elgazzar and Hanafy, 2016). This 
intrigue gets the consideration of strategy creators who help to figure the general impacts of these monetary markers and fuse them in their arrangements. The speculators and the whole masses likewise advantage from it since the mindfulness will assist the financial specialists with making educated venture choices while the open plan to modify for the stun it brings.

The exhibition of a country's financial exchange by and large decides the monetary presentation of the nation (Gatsimbazi, jaya, mulyungi and Ochieng, 2018). An expanding offer value list extra time shows strength of the economy while a falling offer value list demonstrates a temperamental economy. A few examinations have been done on the impact of macroeconomic pointers on financial exchange execution, yet there has not been an accord on the genuine outcomes of these factors on securities exchange execution of nations. The instability in the financial exchange conduct in Nigeria reflects in the stock costs which have been temperamental. In the late 1990s and mid-2000, numerous financial specialists lost their speculations because of the huge fall in the costs of offers. It was a stun that influenced both the speculators and even the monetary examiners who give proficient manual for financial specialists on venture choices. Be that as it may, this investigation is centered around deciding the effect of macroeconomic factors on securities exchange execution in Nigeria.

\subsection{Objective of the Study}

The general objective of the study is to evaluate the impact of economic indicators on capital market performance in Nigeria. The study also seeks to achieve the following specific objectives:

1. To examine the effect of Gross Domestic Product (GDP) on capital market capitalization;

2. To assess the impact of interest rate on capital market capitalization;

3. To investigate the influence of inflation rate on capital market capitalization;

4. To determine the extent to which exchange rate affects capital market capitalization.

\subsection{Hypotheses}

To pursue the above research objectives, the following null hypotheses have been formulated:

$\mathrm{Ho}_{1}$ : Gross domestic product does not significantly affect the capital market capitalization;

$\mathrm{Ho}_{2}$ : Interest rate does not significantly influence the capital market capitalization;

$\mathrm{Ho}_{3}$ : The inflation rate does not have significant impact on capital market capitalization;

$\mathrm{Ho}_{4}$ : Exchange rate does not have significant effect on capital market capitalization.

\section{Literature Review}

The literature review for this study has been divided into three phases which comprises the conceptual framework, theoretical and empirical reviews.

\subsection{Conceptual Framework}

The examination of theoretical and empirical literatures shows that the following economic forces can potentially influence the capital market performance. These economic indicators include: the Gross domestic product (GDP), interest rate, inflation rate and exchange rate. Thus, the conceptual framework is summarized below:

\section{Explanatory Variables}

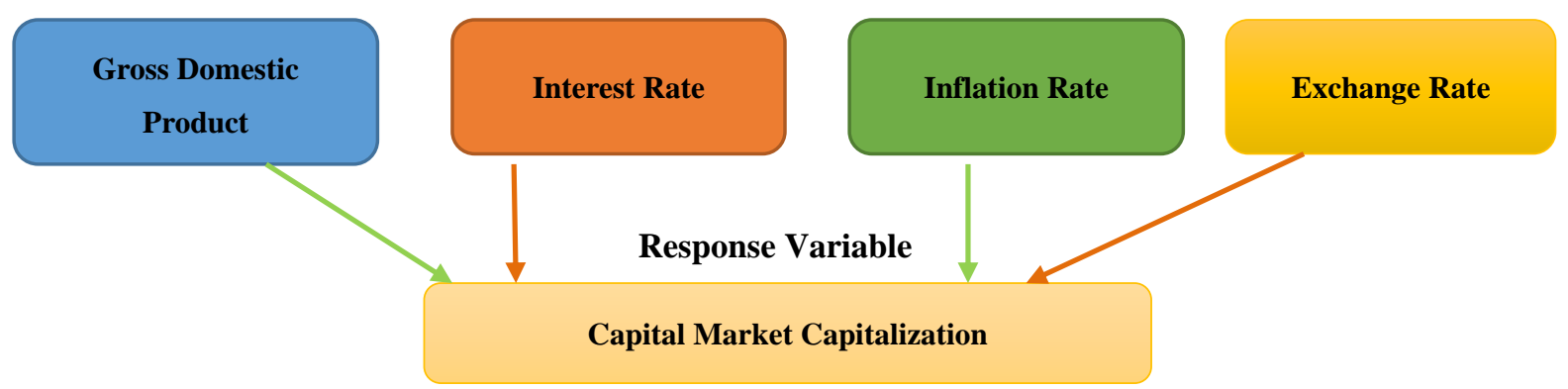

Figure 1. Conceptual framework

Source: Author's Desk Research, 2019 


\subsubsection{Market Capitalization and Equity}

Market capitalization is the total monetary value of all outstanding shares of a company (Chen, 2018). It is calculated by multiplying the current share price by the number of outstanding shares. Market analysts normally apply this figure to represent a company's size, as many stock market indexes are weighted by market capitalization. Owing to the fact that market capitalization is a function of share price, it can vary greatly from month to month, or even from day to day (Chen, 2018; Maverick, 2019). Outstanding shares refer to a company's existing stock in the hands of its shareholders, including share blocks held by institutional investors and restricted shares owned by the company's officers and insiders (Chen, 2018). Outstanding shares are shown on a company's balance sheet under the heading "Capital Stock." The number of outstanding shares is used in calculating key metrics such as a company's market capitalization, as well as its earnings per share (EPS) and cash flow per share (CFPS). A company's number of outstanding shares is not static and may fluctuate wildly over time. Market capitalization does not measure the equity value of a company. In Nigeria, Market capitalization (also known as market value) is the share price times the number of shares outstanding (including their several classes) for listed domestic companies.

Shareholder equity is referred to as a more accurate assessment of a company's actual net worth (Maverick, 2019). Equity is a simple statement of a company's assets minus its liabilities; it could also be seen as the net profit that would remain if the company was sold or liquidated at fair value. Unlike market capitalization, equity does not fluctuate day to day based on stock price (Maverick, 2019).

\subsubsection{Gross Domestic Product and Capital Market Performance}

Bojana and Tino (2016) asserted that capital markets in transition countries can be described as underdeveloped and cannot influence any national economic progress particularly when compared with what is obtainable in the industrialized economies. Total national output (GDP) gives a thorough score card about the general wellbeing of an economy. Along these lines, financial specialists are especially worried about a countries GDP report in each speculation choice. Positive monetary development of a nation is generally observed in the size of the GDP which lifts corporate benefits just as financial exchange execution (Mburu, 2015). This infers a waning financial development prompts a negative impact on securities exchange execution.

\subsubsection{Interest Rate and Capital Market Performance}

The key capacity of a securities exchange is to go about as a middle person among borrowers and banks (Issahatu, Ustarz and Domanban, 2013) in getting capital at a common financing cost. Securities exchanges empowers loan specialists (Banks and other money related foundations) to give credit offices to people and firms who thus utilize the assets for interest in stocks. The connection between securities exchange and loan fee is a mix of obligation and value financing. On the off chance that the pace of premium paid by banks to contributors is expanded, speculators will belittle the banks the more and less financial specialists will put resources into the securities exchange (Winful, Sarpong and Sarfo, 2016). This communication diminishes securities exchange execution just as the profitability of the economy. Then again, high loan fee builds the expense of getting and simultaneously decreases corporate benefit and profits, in this manner influencing offer costs of firms.

\subsubsection{Inflation Rate and Capital Market Performance}

Increment in swelling rate expands the average cost for basic items which moves rare assets from interest in stocks to family unit utilization. Inflationary financial circumstance results to diminish in the interest for interest in stocks. There is constantly a negative relationship among's swelling and securities exchange execution. Expansion isn't useful for any economy since it influences every one of the portions, distorts costs and undermines the unmistakable relationship that is fundamental to exist among worth and cost of an item or administration (Gurioveleen and Bhatai, 2015). The connection among swelling and financial exchange execution can be certain or negative contingent upon whether the economy is stood up to with anticipated or unanticipated expansion (Talla, 2013). On the off chance that the swelling is envisioned, an expansion in costs would result to increment in the organizations' income which would prompt paying more profits and henceforth increment the cost of the organizations' stocks. Be that as it may, if swelling is unforeseen, an expansion in costs would expand typical cost for basic items which thusly moves assets from ventures to utilization along these lines having negative impact on financial exchange costs.

\subsubsection{Exchange Rate and Capital Market Performance}

Swapping scale is the estimation of one cash with the end goal of transformation to another. Swapping scale developments significantly influence the securities exchange returns because of its data substance to the speculators. Money instability influences stock returns and when it acknowledges, particularly on the off chance that it is a fare situated nation, it makes the fares less alluring along these lines hurting the household financial exchange. Under this 
situation, the cited organizations doing the fare in the nation become less productive and less alluring to speculators, therefore the financial exchange loses (Muthike and Sakwa, 2012). The recurrence of conversion scale variance majorly affects the money related market (Mechri, Hamad, Peretti and Charfi, 2019). In spite of the fact that the turnaround is the situation in a circumstance where the nation's money devalues.

\subsection{Theoretical Review}

Efficient Market Hypothesis and Arbitrage Pricing Theory (APT) are the theories supporting this study.

\subsubsection{The Efficient Market Hypothesis}

The effective market theory is connected with Fama (1970) who originally utilized the expression "proficient market". Fama (1970) characterized proficient market as a market where stock costs consistently mirror all accessible data. The productive market theory is in three structures which include: the feeble structure, semi-solid structure and the solid structure. This examination finds the semi-solid structure increasingly appropriate in light of the fact that in this market, stock costs mirrors all openly accessible data. This is the reason stock costs vacillates in light of the fact that every single macroeconomic variable influencing an association's stock must be assessed to decide its offer cost under the semi-solid type of proficient economic situation. Data on macroeconomic factors are for the most part in the open area through distributions by the World Bank, International Monetary Fund and Central Banks of countries. Subsequently, organizations working in a specific industry can be effectively checked and offer cost can't be swelled to make benefit since the data about the business is known by everybody. Moreso, speculators ordinarily make shrewd and all around educated venture choices to dodge venture misfortunes coming about because of absence of data.

\subsubsection{Arbitrage Pricing Theory (APT)}

This investigation is upheld by the Arbitrage Pricing Theory which clarifies the connection between stock costs and macroeconomic factors (Ross, 1976; Chen, Roll and Ross, 1986). There are different experimental confirmations uncovering that macroeconomic variables are related with financial exchange execution. As indicated by Naik and Padhi (2012), the relationship of some macroeconomic factors with stock costs shifts from market to showcase and can change contingent upon the periods under thought. Ross (1976) presents that the essential impacts on stock returns generally exude from macroeconomic powers, for example, swelling rate, loan fee, swapping scale, moves in hazard premiums, modern creation and the degree of financial development. Chen et al. (1986) accept that individual stock relies upon both expected and unforeseen macroeconomic factors which perpetually decide the arrival acknowledged by financial specialists.

\subsection{Empirical Review}

The exact audit is a make-up of concentrates from various nations on the planet where fluctuating timespans, measurable devices and macroeconomic pointers were connected to survey of the effect of macroeconomic factors on securities exchange execution. Thus, the discoveries vary contingent upon the financial condition considered, macroeconomic elements utilized and the timeframes secured.

Nopphon (2012) study was an absolute logical inconsistency and deviation from the general conviction that macroeconomic factors influence securities exchange execution. Utilizing Thailand as a contextual analysis, the investigation secured a period from 2001 to 2010 and found that stock return was a superior monetary pointer that could anticipate the conduct of macroeconomic factors. At the end of the day, macroeconomic factors were discovered insufficient in deciding securities exchange execution in Thailand. Tella (2013) analyzed the effect of chosen macroeconomic factors on stock costs of the Stockholm Stock Exchange (OMXS30) from 1993 to 2012 utilizing customary least squares (OLS) system. The examination discovered proof that swelling and cash devaluation had huge negative effect on stock costs while loan cost had an immaterial negative effect on stock costs, however cash supply applied an inconsequential positive impact on stock costs.

Issahaku et al. (2013) contemplated the connection between macroeconomic factors and stock returns in Ghana from 1995 to 2010. The examination found the presence of a long run connection between stock returns and the free factors which involved expansion, cash supply and outside direct venture (FDI). In the short run, a solid relationship likewise existed between stock returns and loan fee, expansion and cash supply. Barno (2014) lengthened the examination in Ghana by looking at the effect of macroeconomic factors on financial exchange execution in Ghana from 2000 to 2013 utilizing normal least squares (OLS) estimation method. The discoveries uncovered that loan fees and cash supply had a critical negative effect on financial exchange returns while conversion standard had a huge constructive outcome on securities exchange returns, however swelling rate had no impact on financial exchange returns. 
Arnes (2014) researched Istanbul Stock Exchange in Turkey, the G20 economy from 1994 to 2013 utilizing stock records as intermediary for securities exchange execution. The discoveries uncovered that mechanical generation had a negative and immaterial effect, hence indicating help for proficient market speculation which proposes that all data about the business is in the open area for speculators to settle on an educated venture choice. The aftereffect of the examination likewise uncovered that between bank loaning rate had a noteworthy negative association with market returns while the outcome for the remainder of different factors were conflicting inside the period considered. Sukruoglu and Nalin (2014) studied the role and effects of macroeconomic variables on stock market development in selected European countries using panel data from 1995 to 2011. The study found evidence that monetization and inflation had negative effects on stock market development while income, liquidity ratio, saving rate exerted positive influence on stock market development.

Khodaparasti (2014) utilized multi-relapse investigation to survey the impact of macroeconomic factors on the financial exchange execution in Iran from 2007 to 2011. The result of the examination demonstrated that swapping scale and mechanical file had huge positive effect on the financial exchange while expansion applied an irrelevant effect on the securities exchange execution. Hsing (2014) investigated the impacts of macroeconomic factors on the stock market in Estonia. The paper found that the stock market index of Estonia was favourably affected by the macroeconomic variables which included real GDP, debt/GDP ratio and the German stock market index. On the contrary, there was an existence of a negative correlation between the Estonia stock market index and exchange rate, domestic interest rate, expected inflation rate and the Euro area government bond yield. Ouma and Muriu (2014) utilized the conventional least square (OLS) method to survey the effect of the macroeconomic factors on stock returns in Kenya from 2003-2013. The discoveries uncovered that cash supply and expansion had huge positive effect on financial exchange returns, while swapping scale affected securities exchange returns. In any case, financing cost did not apply any impact on securities exchange returns.

Gurioveleen and Bhatai (2015) completed an examination on the effect of macroeconomic factors on Indian Stock Market utilizing assembling firms as contextual investigation. A few factual test were run utilizing different monetary markers, be that as it may, remote institutional speculators and swapping scale were discovered critical however with no association with normal shutting costs of assembling firms. The investigation likewise uncovered the presence of powerless type of proficient theory in Indian Stock Market because of the way that the securities exchange file did not have any association with the factors tried for the period secured by the examination. Zhou, Zhao, Belinga and Gahe (2015) used the Calderon-Rosell model to examine the macroeconomic factors affecting the stock market development in Cameroon. The findings of the study showed that stock market liquidity and financial openness were substantial in determining capital market development in Cameroon. Nijam et al. (2015) utilized conventional least square (OLS) technique to explore the effect of macroeconomic factors on financial exchange execution in Sri Lanka from 1980 to 2012. The discoveries uncovered that financial exchange file and macroeconomic factors in Sri Lanka had solid relationship. The investigation likewise settled that GDP, conversion scale and financing cost had huge effect on all offer value record while the parity of installment did not apply any impact.

Barakat et al. (2016) considered the effect of macroeconomic factors on securities exchanges of Egypt and Tunisia from 1998 to 2014. The macroeconomic factor researched include: shopper value file, swapping scale, cash supply and loan fee. The discoveries uncovered that market record had a causal association with shopper value file, conversion scale, cash supply and loan cost in Egypt while in Tunisia, it was just customer value file that did not have causal association with the securities exchange list. Su, Bui and Nguyen (2016) applied a panel data of 36 unindustrialized countries for the period 2003 to 2014 and employed two-way General Method of Moments (GMM) to assess the determinants of capital market development. The results specified that the negative determinant was the money supply while economic growth, domestic credit and stock market liquidity showed positive effects on stock market development of the 36 emerging nations. Winful et al. (2016) explored the effect of macroeconomic factors on financial exchange execution of 41 developing economies utilizing board information from 1996 to 2011. The investigation utilized four systems which include: common least squares (OLS) technique, dynamic standard least squares (DOLS), Newey-West and completely changed conventional least squares (FMOLS) estimators. The outcomes demonstrated that conversion scale deterioration and decline in customer value list effectsly affected financial exchange execution. The investigation additionally settled that expansion in cash supply did not have positive effect on financial exchange execution.

Giri and Joshi (2017) broadened the examination in India utilizing Auto Regressive Distributed Lag (ARDL) procedure and Vector Error Correction Model (VECM) to inspect the long run and short run relationship between macroeconomic factors and the stock costs in India from 1979-2014. The investigation found a long run relationship 
among the factors and set up that expansion, swapping scale and financial development had noteworthy positive effect on stock costs while raw petroleum value influenced stock costs adversely. Golam et al. (2017) utilized normal least squares numerous relapse model to analyze the impact of macroeconomic factors on securities exchange execution of South Asian Association for Regional Cooperation (SAARC) nations from 2005 to 2015. The examination discovered proof that swapping scale, financing cost and remote cash save were all factually noteworthy in impacting securities exchange execution of the SAARC nations while swelling and cash supply did not apply huge effect on the financial exchange returns. Matadeen (2017) used panel vector error correction model to investigate the macroeconomic determinants of stock market development in the Sub-Saharan African Countries. The result showed that economic growth, banking development, stock market liquidity, investment and macroeconomic stability were the major determinants of the stock market development while savings rate had a significant negative effect on the equity market growth of the African countries.

Khalid and Khan (2017) examined the impacts of loan costs, trade rates and swelling rates on securities exchange execution in Pakistan from 1991 to 2017 utilizing ARDL limits and Error Correction Model (ECM). The discoveries uncovered that financing cost had a critical negative effect on securities exchange while conversion scale and swelling rate applied positive impact on financial exchange record. Muhammad, Sonia and Tayyaba (2017) carried out a study on the impact of macro-economic determinants on market capitalization in Pakistan. The established the existence of a robust relationship between capital market capitalization, money supply oil prices and foreign direct investment in Pakistan. In a bid to extend the study, Khan and Khan (2018) assessed the effect of macroeconomic factors on stock costs in Pakistan utilizing Karachi Stock Exchange as a contextual investigation. The investigation secured a period from 2000 to 2016 and found that the stock costs of Karachi Stock Exchange were fundamentally affected by cash supply, swapping scale and loan cost over the long haul while for the time being, every one of the factors did not have impact but rather a negative effect was found with the conversion standard.

Epaphra and Salema (2018) utilized month to month board information of 10 organizations recorded on the Dar es Salaam Stock Exchange of Tanzania from 2012-2016 to look at the effect of macroeconomic factors on stock costs. The relapse result demonstrated that cash supply and conversion scale positively affected stock costs while Treasury bill rate applied a negative effect on stock costs. The examination affirmed that swelling rate did not have any effect on the stock costs. Kamazima and Omurwa (2018) also examined the determinants of financial markets development in Tanzania using secondary data obtained from Dar es Salaam Stock Exchange from 2007 to 2016. The study employed vector autoregressive (VAR) model and came up with the finding that stock market volatility, stock market liquidity and economic growth impacted positively and significantly on financial market development. The result of the study also revealed that inflation rates had an insignificant negative effect on financial market development in Tanzania.

Kunofiwa (2018) examined the determinants of stock market development in emerging market development in the Europe, Latin America and Africa. The study employed secondary data from 1994 to 2014 and made use of pooled ordinary least squares (OLS) method. The findings revealed that FDI, savings, economic growth, trade openness, exchange rates, banking sector development and stock market liquidity affected the development of the emerging nations' stock market positively and substantially. In a similar study, Megaravalli and Sampagnaro (2018) inspected the long run and short run effect of macroeconomic pointers on financial exchanges in ASIAN 3 economies which include: China, India and Japan utilizing month to month time arrangement information from 2008 to 2016. The examination discovered proof that swapping scale had a huge positive effect on the securities exchanges over the long haul while swelling had an immaterial negative effect on the financial exchanges. The factors did not have any measurably critical effect on the securities exchanges in the short run.

Ho and Odhiambo (2018) analyzed the macroeconomic drivers of stock market development in the Philippines from 2001 to 2016. The study specifically examines the impacts of banking sector development, inflation rate, exchange rate, economic growth, trade openness and stock market liquidity on the development of stock market in the Philippine. The findings revealed that trade openness had a negative impact on Philippine stock market development in the long run, while the banking sector development and the exchange rate had positive impacts on the development of the Philippine stock market in the short run. Gatsimbazi et al. (2018) expanded the investigation in Rwanda utilizing month to month time arrangement information which spread over for a time of 6 years. The discoveries uncovered that GDP, swelling and conversion standard had huge negative impacts on financial exchange execution while loan fee applied an irrelevant negative effect on securities exchange execution in Rwanda.

In another local study, Kolapo, Oke and Olaniyan (2018) surveyed the effect of macroeconomic factors on financial exchange execution in Nigeria from 1986 to 2015 utilizing Autoregressive Distributed Lag (ARDL) limits method. 
The investigation discovered proof that Gross local item (GDP) and cash supply impactsly affected financial exchange execution in Nigeria. The examination likewise settled the presence of a long run connection between macroeconomic essentials and securities exchange execution. Azeez and Obalade (2019) applied ARDL bound testing technique to examine the long and short term association between stock market development and macroeconomic determinants which include GDP, banking sector development, stock market liquidity, foreign direct investment, inflation rate and savings rate. The study found that all the macroeconomic variables were significant in determining the stock market development except the savings rate which was not significant in explaining the stock market development in Nigeria.

\subsection{Research Gap}

The majority of the studies reviewed in this paper mainly focused on equity (stock) market development which is just a segment of the capital market. This present study is a holistic study which is concerned about the performance of the capital market in Nigeria. Capital market capitalization used as the proxy for capital market performance comprises total annual market capitalization of the government stocks/securities, debt/bonds, equities and exchange trust fund (ETF) introduced in in Nigeria in 2011. The examinations explored above are done in various economies, which comprise of both rising and created economies, thus the outcomes fluctuate. Nopphon (2012) was an out and out deviation from the bearing of different examinations while a few different investigations utilized macroeconomic factors regular in the nations they assessed. This examination is completed in Nigeria and the most widely recognized economic indicators among others chosen for this investigation are the swapping scale, loan cost, swelling rate and total national output. This determination is upheld by Arbitrage Pricing Theory (APT) Model which communicates that these factors impact on capital market performance. The timespan is from 1998 to 2018 which demonstrates that the investigation is about the latest examination covering the prompt past year.

\section{Methodology}

\subsection{Research Design and Method of Data Analysis}

The examination utilizes a causal research structure which is utilized to investigate the impact of one variable on another variable (Kothari, 2004). This exploration configuration is in concurrence with this investigation which targets building up the effect of economic forces on capital market performance in Nigeria. The free factors include: conversion scale (EXG), loan cost (INT), expansion rate (INF) and Gross residential item (GDP) while the reliant variable is the capital market capitalization (CMC) which is utilized as the proxy for capital market performance in Nigeria. The investigation covers a period from 1998 to 2018 utilizing yearly time arrangement data. The data for CMC were gathered from the Central Bank of Nigeria (CBN) Statistical Bulletin, while the information for EXG, INT, INF and GDP were sourced from the World Bank Development Indicators and International Monetary Fund (IMF). The information were orchestrated in a spread sheet utilizing exceed expectations 2013 programming and because of the variety in the information esteems, every one of the information were logged to accomplish consistency important for the investigation. The investigation utilized Ordinary Least Squares Technique to play out the multi-relapse examination with the guide of Statistical Package for Social Sciences (SPSS) form 20 while E-views 9 was utilized to complete the pattern investigation via plotting of graph. The dismissal paradigm is at 5\% level of centrality. In the event that the p-value surpasses 5\%, the invalid theory (Ho) is acknowledged, yet on the off chance that it is generally the Ho is rejected.

\subsection{Model Specification}

The study adopted the Arbitrage Pricing Theory Model of stock market returns. The model for capital market performance and economic forces determining capital market operation is expressed below:

Capital Market performance $=\mathrm{f}$ (economic indicators).

For the purpose of this study, this model is expressed as follows:

$$
\text { LOGCMC }=\beta_{0}+\beta_{1}(\text { LOGGDP })+\beta_{2}(\text { LOGINT })+\beta_{3}(\text { LOGINF })+\beta_{4}(\text { LOGEXG })+\varepsilon
$$

Where:

$\mathrm{CMC}=$ Capital market capitalization; GDP $=$ Gross domestic product; $\mathrm{INT}=$ Interest rate;

$\mathrm{EXG}=$ Exchange rate; $\varepsilon=$ Error term; $\beta_{0}=$ Constant; $\beta_{1}-\beta_{4}=$ Regression coefficients.

A priori expectation:

$\beta 1, \beta 2, \beta 3, \beta 4>0$ 
The economic a priori expectation is that all the explanatory variables must be greater than zero, indicating a positive influence on capital market performance.

\section{Data analysis and Interpretations}

\subsection{Trend Analysis}
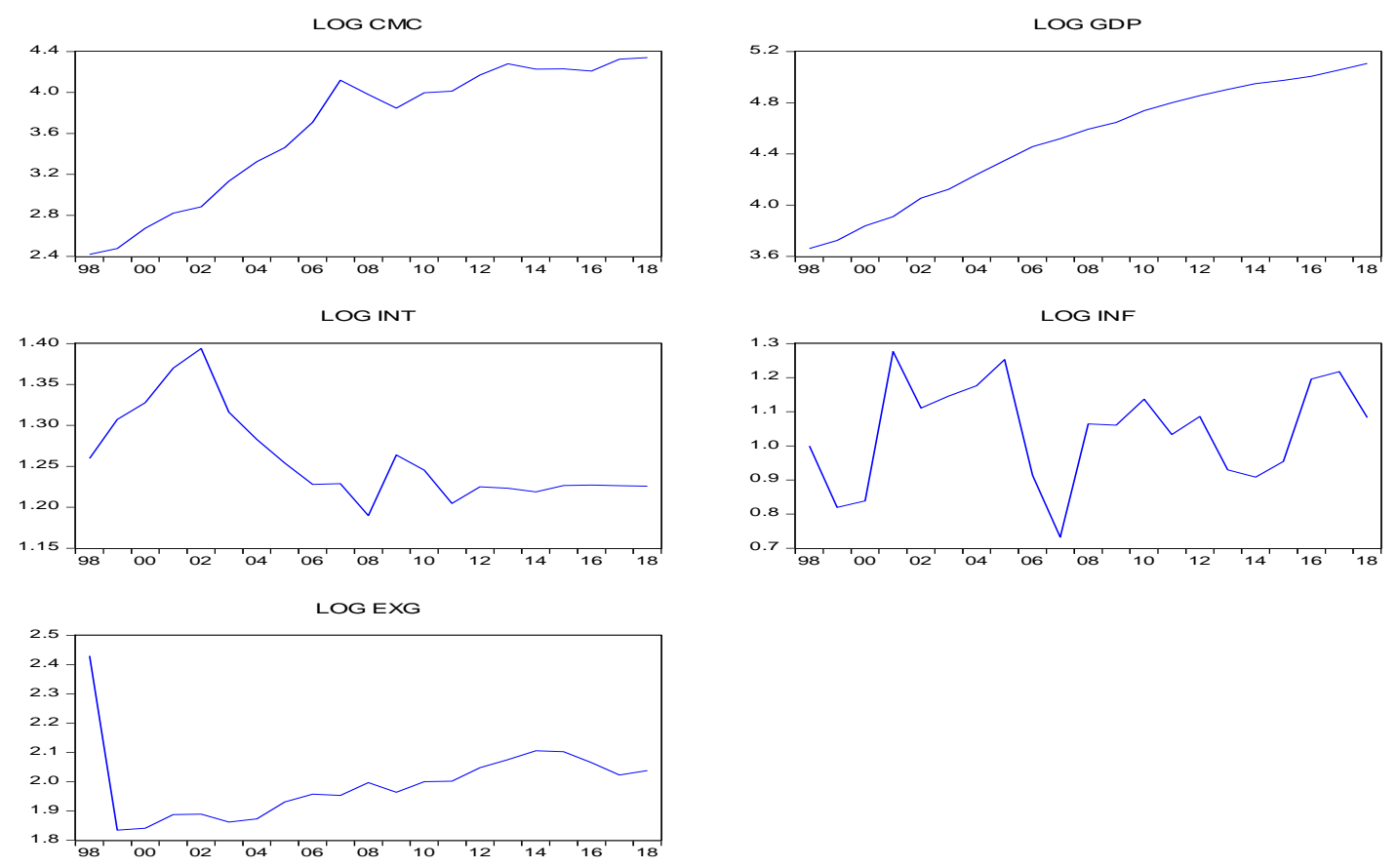

Figure 2. Trend of CMC, GDP, INT, INF and EXG from 1998-2018

Source of Data: Word Bank Development Indicators, IMF and CBN Statistical Bulletin.

Figure 2 above is the trend of all the variables which include capital market capitalization, GDP, interest rate, inflation rate and exchange rate from 1998 to 2018. The trend shows that the CMC rose very high in 2005, but a little drop was noticed in 2006 before the unsteady increase continued. All economic factors have affected capital market performance, but the GDP has the most favorable influence. The concept that the level of growth in an economy has a lot to do in determining capital market performance in a country is confirmed. The fluctuation in the inflation rate is very noticeable and worrisome because a rise in the inflation rate will lead to a decrease in the capital market performance.

Table 1. Model summary of results

\begin{tabular}{llllll}
\hline Model & R & R Square & Adjusted R Square & Std. Error of the Estimate & Durbin-Watson \\
\hline \multicolumn{1}{l}{} & & & & \\
\hline 1 & .987 & .974 & .967 & .11953 & 1.520 \\
\hline
\end{tabular}

Note: a. Predictors: (Constant), EXG, INF, GDP, INT; b. Dependent Variable: CMC

Source: Author's computation, 2019.

Table 1 above shows the model summary of the regression result of the data. The correlation ( $\mathrm{R}$ ) value of is $98.7 \%$ implying that the nexus between capital market capitalization and economic indicators is sturdy and noteworthy. This confirms that the economic forces in Nigeria determine to a very large extent, the capital market operations. The coefficient of determination which is the $\mathrm{R}$ Square is $97.4 \%$. The value shows that the GDP, interest rate, inflation rate and the exchange rate explain up to $97.4 \%$ of the changes in the capital market capitalization in Nigeria while 
the remaining $2.6 \%$ is answerable by other factors that are not reflected in the model. The Durbin-Watson is within the tolerable boundary.

Table 2. Anova result

\begin{tabular}{lllllll}
\hline Model & & Sum of Squares & df & Mean Square & F & Sig. \\
\hline \multirow{2}{*}{1} & Regression & 8.503 & 4 & 2.126 & 148.782 & .000 \\
\cline { 2 - 7 } & Residual & .229 & 16 & .014 & & \\
\cline { 2 - 7 } & Total & 8.731 & 20 & & &
\end{tabular}

Note: a. Dependent Variable: CMC; b. Predictors: (Constant), EXG, INF, GDP, INT

Source: Author's computation, 2019.

From table 2 above, the value of F statistics is 148.782 with the p-value of $0.000<0.05$. Therefore, the outcome is statistically substantial and the model is fitting for the study. The result also shows that the designated economic forces used in this study have joint and huge impact on the capital market performance.

\subsection{Test of Hypothesis}

Table 3. Regression coefficients

\begin{tabular}{|c|c|c|c|c|c|c|c|c|}
\hline \multirow{2}{*}{\multicolumn{2}{|c|}{ Model }} & \multicolumn{2}{|c|}{$\begin{array}{l}\text { Unstandardized } \\
\text { Coefficients }\end{array}$} & \multirow{2}{*}{$\begin{array}{l}\text { Standardized } \\
\text { Coefficients } \\
\text { Beta }\end{array}$} & \multirow[t]{2}{*}{$\mathbf{T}$} & \multirow[t]{2}{*}{ Sig. } & \multicolumn{2}{|c|}{$\begin{array}{l}\text { Collinearity } \\
\text { Statistics }\end{array}$} \\
\hline & & $\bar{B}$ & Std. Error & & & & Tolerance & VIF \\
\hline & (Constant) & 1.640 & 1.673 & & .980 & .342 & & \\
\hline & GDP & 1.248 & .094 & .881 & 13.332 & .000 & .375 & 2.668 \\
\hline \multirow[t]{3}{*}{1} & INT & -2.028 & .895 & -.167 & -2.265 & .038 & .299 & 3.341 \\
\hline & INF & -.183 & .197 & -.041 & -.926 & .368 & .828 & 1.207 \\
\hline & $\overline{\mathrm{EXG}}$ & -.433 & .241 & -.086 & -1.799 & .091 & .719 & 1.391 \\
\hline
\end{tabular}

Note: a. Dependent Variable: CMC

Source: Author's computation, 2019.

$\mathrm{Ho}_{1}$ : Gross domestic product does not significantly affect the capital market capitalization

The study earlier hypothesized that GDP does not significantly influence capital market capitalization in Nigeria. From table 3 above, GDP t-statistics is 13.332 and the p-value is $0.000<0.05$ level of significance. This result

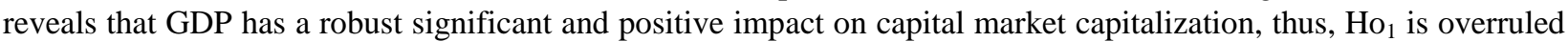
and the alternative which states otherwise established. This result agrees with the findings of (Nijam et al. 2015; Giri \& Joshi, 2017; Kolapo et al., 2018) while conflicting with the findings of Gatsimbazi et al. (2018).

$\mathrm{Ho}_{2}$ : Interest rate does not significantly influence the capital market capitalization

The study initially suggested that interest rate does not have substantial impact on capital market capitalization in Nigeria. Therefore, the result on table 3 above indicates that interest rate (INT) t-statistics is -2.265 with the p-value of $0.038<0.05$. This result entails that interest rate has a significant negative impact on capital market capitalization, therefore, the $\mathrm{Ho}_{2}$ is hereby accepted and the alternative which states otherwise rejected. This result agrees with the findings of (Arnes, 2014; Barno, 2014) whose studies revealed that interest rate had significant negative influence on stock market performance in Turkey and Ghana respectively. However, there is a conflicting result found in the studies of (Nijam et al., 2015; Golam et al., 2017) whose works provided evidence that interest rate positively influenced share prices.

$\mathrm{Ho}_{3}$ : The inflation rate does not have significant impact on capital market capitalization 
The study earlier suggested that inflation rate does not have significant impact on capital market capitalization. However, from table 3 above, the inflation rate (INF) t-statistics is -0.926 with the p-value of $0.368>0.05$. This result implies that the inflation rate has immaterial negative influence on capital market capitalization and $\mathrm{So} \mathrm{Ho}_{3}$ is accepted and the alternative suggestion declined. This result is in agreement with the findings of (Barno, 2014; Golam et al., 2017; Khalid \& Khan, 2017) while disagreeing with the findings of (Ouma \& Muriu, 2014; Giri \& Joshi, 2017) whose studies revealed that inflation rate had significant positive impact on share prices.

$\mathrm{Ho}_{4}$ : Exchange rate does not have significant impact on capital market capitalization

The study earlier hypothesized that exchange rate does not have significant influence on capital market capitalization in Nigeria. From table 3 above, exchange rate $(\mathrm{EXG}) \mathrm{t}$-statistics is -1.799 with the p-value of $0.091>0.05$. This result implies that exchange rate does not have significant impact on capital market capitalization which reflects the overall performance of capital market in Nigeria. Thus, $\mathrm{Ho}_{4}$ is accepted and the alternative suggestion which states otherwise rejected. However, this finding is not consistent with the findings of (Khodaparasti, 2014; Nijam, et al., 2015; Giri \& Joshi, 2017; Golam et al., 2017; Khalid \& Khan, 2017; Epaphra \& Salema, 2018; Megaravalli \& Sampagnaro, 2018) who found in their studies that exchange rate significantly and positively influenced stock market performance. The result also contradicts the findings of Khan and Khan (2018) whose study revealed that exchange rate influenced stock prices of Karachi Stock Exchange in Pakistan significantly and negatively in the short run.

\section{Conclusion and Recommendations}

\subsection{Conclusion}

The investigation assesses the effect of economic factors on capital market performance in Nigeria from 1998 to 2018 utilizing economic forces such as inflation, interest rate, exchange rate and Gross domestic product. The $a$ priori expectation is that these factors referenced above will fundamentally and positively impact the capital market capitalization which is utilized as intermediary for capital market performance in Nigeria. In any case, the measurable proof uncovers that inflation rate and the exchange rate have inconsequential negative impact on the capital market capitalization. The study also finds evidence that interest rate exerts significant negative influence on capital market capitalization while the GDP has a substantial positive effect on capital market capitalization. The findings highlight that GDP is an economic force that significantly and positively affect the capital market performance while the interest rate is on the opposite direction. The policy implication is that the capital market cannot operate without the involvement of the financial institution whose duty is to provide finances at a cost which is the interest. However, it behooves on the Central Bank of the country to properly regulate the interest rate for the progress of the capital market.

\subsection{Proposals}

In view of the discoveries of the investigation, the study recommends that the Central Bank of Nigeria should minimize the high cost of finance in order to encourage investors and other capital market operators in the country. The study finds inflation rate and exchange rate negatively immaterial in influencing the capital market performance, however, it suggests that policy makers should uphold price stability in the country and also guarantee that exchange rate fluctuations are amply synchronized.

The GDP growth is encouraged since the growth of a nations GDP leads to increase in capital market performance, thus, the government should encourage economic growth policies that will stimulate capital market expansion in the country. In a nutshell, it follows that the growth of the economy of a nation, is the growth of its capital market. Thus, this principle should be sustained in Nigeria in order to boost the capital market operations.

\section{References}

Arnes, S. K. (2014). Impact of macroeconomic indicators on stock market performance: The case Of the Istanbul Stock Exchange. M.Sc. Thesis, Copenhagen Business School.

Azeez, B. A., \& Obalade, A. A. (2019). Macroeconomic determinants of stock market development In Nigeria: (1981-2017). AUDE, 15(1/2019), 203-216.

Barakat, M. R., Elgazzar, S. H., \& Hanafy, K. M. (2016). Impact of macroeconomic variables on Stock markets: Evidence from emerging markets. International Journal of Economics and Finance, 8(1), 195-207. https://doi.org/10.5539/ijef.v8n1p195

Barno, C. (2014). The effect of macroeconomic variables on stock market returns in Ghana (2000-2013). PhD Dissertation, Walden University Scholar Works. 
Bojana, O. D., \& Tino, K. (2016). Determinants of capital market in the new member EU Countries. Economic Research-Ekonomska Istrazivanja, 29(1), 758-769. https://doi.org/10.1080/1331677X.2016.1197551

Chen, J. (2018). Market capitalization. Retrieved on September 4, 2019 from https://www.investopedia.com/terms/m/marketcapitalization.asp

Chen, N. F., Roll, R., \& Ross, S. A. (1986). Economic forces and the stock market. Journal of Business, 59, 383-403. https://doi.org/10.1086/296344

Epaphra, M., \& Salema, E. (2018). The impact of macroeconomic variables on stock prices in Tanzania. Journal of Economic Library, 5(1), 12-41.

Fama, E. (1970). Efficient capital markets: A review of theory and empirical work. The Journal of Finance, 25(2), 383-417. https://doi.org/10.2307/2325486

Gatsimbazi, I., Jaya, S., Mulyungi, P., \& Ochieng, A. (2018). Effects of macroeconomic variables on stock market performance in Rwanda, Case study of Rwanda Stock Exchange. European Journal of Economic and Financial Research, 3(1), 104-125.

Giri, A. K., \& Joshi, P. (2017). The impact of macroeconomic indicators on India Stock Prices: An Empirical analysis. Studies in Business and Economics, 12(1), 61-78. https://doi.org/10.1515/sbe-2017-0005

Golam, M., Wali, U., Ashraful, I., Alam, S., \& Khan, K. (2017). Effect of macroeconomic variables on stock market performance of SAARC countries. Asian Economic and Financial Review, 7(8), 770-779. https://doi.org/10.18488/journal.aefr.2017.78.770.779

Gurioveleen, K., \& Bhatai, B. S. (2015). An impact of macroeconomic variables on the functioning of Indian Stock Market: A study of manufacturing firms of BSE 500. Journal of Stock \& Forex Trading, 5(1), 1-7.

Ho, S. Y., \& Odhiambo, N. M. (2018). Analysing the Macroeconomic Drivers of Stock Market Development in the Philippines. Cogent Economics \& Finance, 6(1), 1-18. https://doi.org/10.1080/23322039.2018.1451265

Hsing, Y. (2014). Impacts of Macroeconomic Factors on the Stock Market in Estonia. Journal of Economics and Development Studies, 2(2), 23-31.

Investopedia. (2019). The difference between a capital market and the stock market. Retrieved September 5, 2019, from

https://www.investopedia.com/ask/answers/021615/whats-difference-between-capital-market-and-stock-market. asp

Issahaku, H., Ustarz, Y., \& Domanban, P. B. (2013). Macroeconomic variables and stock market Returns in Ghana: Any causal link?. Asian Economic and Financial Review, 3(8), 1044-1062.

Kamazima, B. K., \& Omurwa, J. K. (2018). The determinants of emerging financial markets Development: A case study of the Dar es Salaam Stock Exchange, Tanzania. European Journal of Business and Management, 10(17), 92-108.

Khalid, W., \& Khan, S. (2017). Effects of macroeconomic variables on the stock market volatility: The Pakistan Experience. International Journal of Econometrics and Financial Management, 5(2), 42-59. https://doi.org/10.12691/ijefm-5-2-4

Khan, J., \& Khan, I. (2018). The impact of macroeconomic variables on stock prices: A case study of Karachi Stock Exchange. Journal of Economics and Sustainable Development, 9(13), 15-25.

Khodaparasti, R. B. (2014). The role of macroeconomic variables in the stock market in IRAN. Polish Journal of Management Studies, 10(2), 54-64.

Kolapo, F. T., Oke, M. O., \& Olaniyan, T. O. (2018). Unravelling the impact of macroeconomic Fundamentals on stock market performance in Nigeria: An ARDL-bound testing approach. Journal of Economics, Management and Trade, 21(3), 1-15. https://doi.org/10.9734/JEMT/2018/40177

Kothari, C. (2004). Research methodology: Methods \& techniques (2nd ed.). Newage International Publishers, New Delhi, India.

Kunofiwa, T. (2018). What are the determinants of stock market development in emerging Markets?. Academy of Accounting and Financial Studies Journal, 22(2), 1-11. 
Matadeen, S. J. (2017). The macroeconomic determinants of stock market development from An African perspective. Theoretical Economics Letters, 7, 1950-1964. https://doi.org/10.4236/tel.2017.77132

Maverick, J. B. (2019). Market capitalization Vs. Equity: What's the Difference?. Retrieved from https://www.investopedia.com/ask/answers/122314/what-difference-between-market-capitalization-and-equity.a $\mathrm{sp}$

Mburu, D. M. (2015). Relationship between exchange rate volatility and stock market Performance. M.Sc. research project, the University of Nairobi.

Mechri, N., Hamad, S. B., Peretti, C., \& Charfi, S. (2019). The impact of the exchange rate Volatilities on stock markets dynamics: Evidence from Tunisia and Turkey. Hal archives: Hal id: hal-01766742v2. https://doi.org/10.2139/ssrn.3304040

Megaravalli, A. V., \& Sampagnaro, G. (2018). Macroeconomic indicators and their impact on stock Markets in ASIAN 3: A pooled mean group approach. Cogent Economics \& Finance, 6, 1-14. https://doi.org/10.1080/23322039.2018.1432450

Muhammad, A., Sonia, S., \& Tayyaba, Z. (2017). The Impact of Macro-economic Determinants on Market Capitalization: An Empirical Analysis in Context of Pakistan. The International Journal of Business \& Management, 5(4), 185-191.

Muthike, S. W., \& Sakwa, M. M. (2012). Can macroeconomic indicators be used as predictors of the stock exchange index trends? A look at the Nairobi stock exchange. In Scientific Conference Proceedings. Retrieved from http://elearning.jkuat.ac.ke/journals/ojs/index.php/jscp/article/view/731

Naik, P. K., \& Padhi, P. (2012). The impact of macroeconomic fundamentals on stock prices Revisited: Evidence from Indian Data. Eurosian Journal of Business and Economics, 5(10), 25-44. https://doi.org/10.2139/ssrn.2150208

Nijam, H. M., Ismail, S. M. M., \& Musthafa, A. M. M. (2015). The impact of macroeconomic Variables on stock market performance: Evidence from Sri Lanka. Journal of Emerging Trends in Economics and Management Sciences, 6(2), 151-157.

Nopphon, T. (2012). Macroeconomic factors of emerging stock market: The evidence from Thailand. International Journal of Financial Research, 3(2), 105-114. https://doi.org/10.5430/ijfr.v3n2p105

Ouma, W. N., \& Muriu, P. (2014). The impact of macroeconomic variables on stock market returns In Kenya. International Journal of Business and Commerce, 3(11), 1-31.

Ross, S. A. (1976). The Arbitrage Theory of Capital Asset Pricing. Journal of Economic Theory, 13, 341-360. https://doi.org/10.1016/0022-0531(76)90046-6

Su, D. T., Bui, T. M. H., \& Nguyen, V. B. (2016). Determinants of Stock Market Development: The Case of Developing Countries and Vietnam. Journal of Economic Development, 24(1), 32-53. https://doi.org/10.24311/jed/2017.24.1.05

Sukruoglu, D., \& Nalin, H. T. (2014). The Macroeconomic Determinants of Stock Market Development in Selected European Countries: Dynamic Panel Data Analysis. International Journal of Economics and Finance, 6(3), 64-71. https://doi.org/10.5539/ijef.v6n3p64

Talla, J. T. (2013). Impact of macroeconomic variables on the stock market prices of the Stockholm Stock Exchange (OMXS30). M.Sc. Thesis, Jonkoping International Business School, Jonkoping University.

Winful, C. E., Sarpong, D. Jr., \& Sarfo, A. K. (2016). Macroeconomic variables and stock market Performance of emerging countries. Journal of Economics and International Finance, 8(7), 106-126. https://doi.org/10.5897/JEIF2016.0743

Zhou, J., Zhao, H., Belinga, T., \& Gahe, Z. S. Y. (2015). Macroeconomic Determinants of Stock Market Development in Cameroon. International Journal of Scientific and Research Publications, 5(1), 1-11. 